\title{
A narrativa na trama da subjetividade: perspectivas e desafios
}

\author{
Amauri Carlos Ferreira* \\ Yonne de Souza Grossi**
}

Contra a fugacidade, a letra.

Contra a morte, o relato.

T.E. Martinez

Pela narrativa de Ovídio, sabe-se que Aracné, exímia tecelã, esqueceu-se de sua dimensão humana e, numa atitude de imprudente soberba, pretendeu dever seu talento apenas a si mesma. Isolou-se, na presunção de que seus trabalhos eram inigualáveis. Perdeu, então, o contato com sua mestra divina Palas Atena, a mãe da tecelagem. Numa atitude maternal a deusa, disfarçada de velha, aconselhou-a a se arrepender. Insultada, ouviu um desafio para que seus trabalhos fossem comparados. Ofendida, Palas Atena aceitou o desafio. Ambas teceram histórias. Atena teceu sobre as metamorfoses através das quais certos deuses punem seus rivais; teceu também a si própria e outros deuses em sua grandeza. Aracné, por sua vez, desenhou histórias maliciosas das metamorfoses e das intrigas entre os deuses. Sutil malevolência e reprovação perpassavam suas histórias. A despeito da perfeição do trabalho de

* Professor do Departamento de Filosofia e Teologia da PUC - MG e do Instituto Santo Tomás de Aquino (ISTA) - Belo Horizonte.

* Professora do Departamento de Sociologia e Relações Internacionais da PUC - MG. 
sua discípula, Atena o rasga e fere sua rival com uma agulha. Aracné, insultada, enforca-se. A deusa sustenta-a no ar e não a deixa morrer. Transforma-a em aranha e lhe diz que, se quisesse tecer, que tecesse.

À semelhança do mito de Aracné, as histórias narradas amealham vozes revividas e constelações de imagens, enredando os fios da existência. Mobilizam um outro universo, emaranhado portador de memória e de experiência do vivido. Criam disponibilidade para o encontro e a presença. Asseguram o vínculo entre o sujeito e suas interações no mundo. Devolvem uma história através de palavras, conferindo-lhe um passado, trançando identidades. Tornam possível a travessia do relato individual, nomeado e singularizado, para a engenhosa construção do coletivo. As histórias narradas abrem a cena para o nós coletivo, quando dão lugar em si para um perceber exterior a si mesmo. Há um reconhecimento sensível de um pelo outro. Trata-se de uma recomposição, relacionando questões que abrem perspectivas novas para se interpretar narrativas no plano da história e do discurso, registrando seus desafios. Analisar a oralidade e seus desdobramentos constitui a matriz de nossos objetivos. Seus patamares balizam instâncias performativas: memória e subjetividade, no percurso ético do outro. Sua tópica é a narrativa.

\section{Lugares}

Como se tece uma lembrança? Uma lembrança que conduz quem lembra aos construtos de si mesmo? À "confirmação de seu mito pessoal em que se reconhece e deseja ver-se reconhecido"? (Santiago, apud Melo Miranda, 1992, p. 120) Opera-se uma reterritorialização do vivido, "um esgueirar pelos cantos", ecoando e modulando o tecido de uma história com os fios da experiência trançada. A diferença se faz na urdidura que não contém os fios tecidos pelo outro. Na saga de Aracné, idéias e imagens do presente reatualizam o passado. Não se trata, no entanto, do fio de Ariadne, mas da tecelagem de Aracné perfazendo metamorfoses, recriando subjetividades demandadas pela diferença.

Para os povos ágrafos, a memória é o repositório de feitos e de fatos. Tendo em vista a garantia de sua manutenção, de forma cuidadosa, era escolhido o "pastor da memória", encarregado de guardar o 
legado que seria entregue a seu sucessor. O guardião da memória articulava fatos e sua representação, vivificando o passado para o grupo haja vista que apenas para os loucos a memória não existe como história. Os loucos vivem o "sem tempo" de suas alucinações. A loucura não tem passado: como "tempo de loucura", existe "a presentificação constante de seus traumas”. Não há portanto, uma memória coletiva. Essa possibilidade é colhida pela razão quando circunscreve o itinerário da memória (Giron, 2000, p. 23).

De origem latina, a palavra memória significa "o que lembra". Todavia, do ponto de vista histórico, a palavra memória guarda uma deusa: Mnemósine. Segundo Hesíodo, ela é a "rainha das colinas de Eleutera”, ou seja, a terra da liberdade completa. Memória nasce dos amores entre Urano (céu) e Géa (terra), sendo ao mesmo tempo protetora da justiça e da vingança. Realiza a ligação entre o mundo real (terra) e o mundo da representação do Urano (céu). Da união entre Zeus e Mnemósine nasce a musa Clio, a história, cujo berço é o cume do poder terrestre e a configuração do passado.

A memória no segmento medieval adquire outro significado, parecendo ter presente a lembrança de Deus. Por essa possibilidade Santo Agostinho a considera um lugar divino, pois nela moram idéias inatas, ou seja, a memória coletiva. A memória faria ponte entre o céu (passado) e a terra (presente), o elemento de ligação entre o homem e Deus (Idem, p. 25).

Já o homem do Renascimento privilegia Géa onde o espaço terrestre é mais valioso do que as lembranças. Os pensadores modernos ocupam-se com a descoberta de novos mundos e novos conhecimentos. Locke nega a existência de idéias inatas, o homem conheceria o mundo de forma indutiva, preenchendo o vazio de sua mente com as sensações colhidas pelos sentidos. À memória caberia um papel de lembrança do entendimento das coisas e do mundo. Nela não habitariam nem deusas nem deuses. Ora, se não existem idéias inatas Deus não pode morar na memória humana. Eis que Locke, no século XVII, interdita a possibilidade de Deus habitar a mente humana desde sempre. Decorre, então, a dessacralização da memória.

A concepção histórica dos gregos e suas derivações permanecem ao longo dos séculos. Hoje, consideramos a história como o permanente entrelaçar-se de continuidades e rupturas, a coexistência dos 
tempos lentos e rápidos, dirá Braudel. A grande dificuldade é que esses tempos apresentam-se simultaneamente. Então, o evento, a rápida transformação, mesmo a revolução, não são rupturas que tudo alteram, pois lentamente é que se modificam hábitos, práticas cotidianas, certos atavismos que resistem a toda novidade. "É que, se o novo insiste em nascer, e o faz quase sempre com a estridência do grito, o velho resiste e não desaparece abruptamente. Daí que a história seja a lenta presença de um luto lento e de uma aurora que, prenunciada, não é tão imediata quanto faz crer sua luz, que parece tudo querer inaugurar" (Paula, 2001, p. 7).

Donde a pergunta: o que é ter uma história? Seria possível pensar que ter uma história significa passar por ações transformadoras. Transformações estas que podem ter o registro do documento escrito ou estriar marcas que tangenciam a oralidade. Também o sujeito vive em um contexto, sendo de suas relações e tensões que emerge sua história. É quando se faz apelo à memória, "princípio de unidade e de continuidade, ponte que assegura o vínculo entre o sujeito e suas experiências" (Mitre, 2001, p. 2). A memória, da qual se alimentam as narrativas. Assim, "os relatos vão devolver a história através de suas palavras, conferindo-lhe um passado, trançando identidades" (Thompson, 1992, p. 337).

A tentativa é procurar, como lembra Roland Barthes (Samain, 2000, p. 2), a estrutura que liga relatos pessoais do vivido e rememorado a uma interpretação consistente, capaz de compreender, desvendar e enunciar nos moldes exigidos pela ciência. O constante é a possibilidade de contato com o presente, em que o narrador não é apropriado pela posição ou discurso do entrevistador, mas se expressa em sua maneira de existir ao "afirmar todas as suas redes vivenciais, todas as suas determinações, caminhos e tecidos particulares, todas as suas diferenças, corpos, visões, desejos, sonhos..." (Caldas, 2001, p. 1). O sentido não é reproduzir o acontecido e sim construir o vivido através de palavras, imagens, discursos. Confere-se ao sujeito o poder de dizer, dizer-se, dizer-nos, o poder de resistir em sua singularidade, procurando apenas uma abertura dialógica. A atitude não é a de domesticar o sujeito transformando-o em depoimento ou dado "mas dar mais nitidez aos horizontes e eixos" da narrativa para se compreender como o mundo incita transformações e sua ordem dificulta escapes (Idem, 2001, p. 2-3). 
Caldas designa como cápsula narrativa a uma organização em que homens e fatos se dispõem de modo fragmentar, heterogêneo, sem estrutura preestabelecida, onde temporalidades aparentemente díspares se superpõem. Não se trata de uma projeção do sujeito mas "texto vivo", momento narrativo com suas "contradições insolúveis", junção de "rosto e massa", integração de "memória e esquecimento", conjuração do permitido e do negado. Pode-se apreender uma vida vivida e contada como uma "escolha narrativa", ou seja, "o ordenamento, o princípio, meio e fim com seu encadeamento, expressão de um narrar e não de um ter vivido" (Caldas, 2001, p. 4-5). As singularidades ordenam e ordenam-se na narrativa em que imagens, eixos vivenciais, módulos de significação se expressam em palavras instauradoras de sentido.

Numa perspectiva paralela, Daisy Perelmutter observa que historiadores orais, ao produzirem e interpretarem seus documentos, deparam-se com a subjetividade. Esta é "mais extensa e mundana" que a interdita figura criada pela modernidade, considerada fundadora e ordenadora de cada indivíduo particular. Ademais, como é de domínio público, promover a coesão, a consciência e o sentimento de identidade, não contemplados pela documentação escrita, foi, ao longo dos anos 1980, cedendo lugar a preocupações de ordem teórico-metodológicas: implantar projetos, transcrever depoimentos, relacioná-los, arquivá-los, analisá-los, adaptá-los a práticas museológicas, pedagógicas, televisivas. Emergir do ostracismo e do descrédito a que fora condenada pela história, tornou-se "um processo lento, turbulento e desconcertante" (Perelmutter, 1998, p. 856). Não mais uma visão unitária, retilínea, do que seria a história oral.

Questões que tangenciam compromissos hoje começaram a criar raiz. Entre outras, "a consciência de que a história oral resulta de uma relação entre sujeito e sujeito, o que implica em co-autoria e, portanto, na falta de controle e autoridade do historiador sobre a sua fonte; sua concepção como uma narrativa, como um tipo específico de construção do discurso e que apresenta uma trama e um enredo próprio; a consideração da memória como matéria e objeto de interesse do historiador; [...] a história oral como um canal de comunicação entre o puramente individual e a paisagem cultural; sua definição como estudo das representações do presente sobre o passado" (Idem, p. 256-7). 
A subjetividade passará então a ter seu estatuto que, para Perelmutter, sustenta-se em quatro pilares: o da subjetividade enquanto emoção, o da subjetividade enquanto faculdade psicológica semelhante à imaginação e ao sonho, o da subjetividade enquanto identidade individual, e mesmo coletiva inconsciente. Identidade esta na configuração instaurada pelos tempos modernos (Grossi, 1997, p. 37).

Também os sólidos, sensíveis e interdisciplinares trabalhos de Alessandro Portelli e Luiza Passerini (Portelli, 1996, 2001; Passerini, 1993) enveredam pelo campo da subjetividade. Não pretendem desatar os emaranhados conteúdos da subjetividade, mas difundir uma espécie de escuta sensível neste território alagadiço e escorregadio. Mostram que, muitas vezes, onde pairam esquecimento, omissão, conivência silenciosa, percebe-se que a subjetividade não guarda nada de individual e transcendente, sendo fundamentalmente coletiva, fundada no embate com o real. (Portelli e Passerini, apud Perelmutter, 1998, p. 858-9).

Apreender a subjetividade não significa identificar formas através das quais ela se reconhece e é reconhecida. Implica apreender o processo de emergência das figuras que ela desenha. Constitui a própria trama uma vez que não possui um antes já dado. Trata-se da composição dos diversos universos que habitam cada existência em seu estar no mundo. Universos estes sempre sujeitos a novos arranjos, a novas errâncias, dependendo da força dos condicionamentos sociais. O próprio corpo não se comporta como um invólucro amorfo e apático onde se passa a existência, endossando de forma viscosa mensagens elaboradas pela consciência. $\mathrm{Na}$ realidade, o corpo possui multifacetadas vozes, passíveis de serem ou não vazadas, dependendo da fluidez do espaço subjetivo que lhe serve de ethos.

Há texturas da existência quando contemplamos um corpo desvitalizado, abstinente; um corpo sensual, quente, experimentador; um corpo que só se explicita a partir de operadores incorporais, como pai, empregado, patrão; um corpo que evoca a sua liberdade; um corpo ambíguo. Todos esses e demais enunciados podem ser inscritos sobre o corpo e percebidos na prática da história oral. Constituem preciosidades de que se dispõe para interpretar manifestações humanas. Há uma polissemia de sentidos que o documento oral engendra: expressões faciais, gastos, timbre e tonalidade de voz, formas de respiração, regularidade das pausas etc. 
Os relatos orais representam paisagens onde se esboçam algumas das questões, afetos e produções que estão mobilizando certa existência. Expõem o substrato de sua cena e as costuras de seu tecido, celebram transformações como condicionantes da realidade vital. Adestram a sua polifonia, murmuram a sua historicidade.

George Duby, em sua obra Heloisa, Isolda e outras Damas do século $X I I$, assinala que confia nos escritos pesquisados não pela sua verdade, mas pelo que dizem. Importam as imagens que oferecem de uma época ou de uma situação. Assim também com as histórias narradas, pois, como se afirmou antes, "a experiência de um sujeito preciso não escapa das concretudes socioculturais que tensamente o realizam como pessoa" (Kofes, 2001, p. 11, 13). Mas, mesmo quando o registro muda para os relatos orais não se pode ignorar a existência de indícios materializados em documentos escritos, fotos, objetos, ícones etc, a que Kofes (2001, p. 21) denomina inscrições objetivas. Há que se chamar a atenção para o que faz a diferença entre inscrições objetivas e relatos orais.

Aquelas representam temporalidades cristalizadas, marcas que guardam mais o tempo, o qual na oralidade é fluidez, deriva, errância. Há uma dispersão, mesmo pelas distintas temporalidades dos próprios sujeitos que narram. $\mathrm{Na}$ fronteira entre a objetividade e a subjetividade, a escuta é sobre o que pode ser construído, tecido através de indagações sobre uma pessoa. Eis porque é possível se trabalhar em vários tempos simultâneos. A recorrência de figurações permite criar imaginários, demarcando categorias de referência e de interpretação.

Construir itinerários orais lembra uma pergunta de Paul Ricoeur (apud Kofes, 2001, p. 123): "como se pode falar de história de uma vida, se esta não estivesse reunida, e como estaria reunida senão em forma narrativa"? Ricoeur avança que a narração faz parte da vida, antes de exilar da vida na escrita. Narrar (historiar) e contar são intercambiáveis. Daí a importância dada ao enredo, ao tecer do enredo, na configuração narrativa deste autor. $\mathrm{O}$ que armaria o enredo seria o fato de que o mundo exibido por qualquer narrativa é sempre temporal. O tempo torna-se tempo humano na medida em que está articulado de modo narrativo. Trata-se de um tempo que alcança concretude através da realização subjetiva.

Reforça Ricoeur (1983, p. 103) a relevância do enredo como uma malha cujos fios mediadores interligam os acontecimentos e o conteúdo 
da história. Eis porque o autor, ao considerar a narrativa uma forma de linguagem, a considera "um equivalente simbólico da ação e do tempo humano correlato” (Nunes, 1988, p. 77). Portanto, "contando histórias, os homens articulam sua experiência do tempo, orientam-se no caos da modalidade de desenvolvimento, demarcando com intrigas e desenlaces o curso muito complicado das ações reais dos homens. Desse modo, o homem narrador torna inteligível para si mesmo a inconstância das coisas humanas, que tantos sábios, pertencendo a diversas culturas, opuseram à ordem imutável dos astros" (Ricoeur, 1978, p. 16). Em síntese, o enredo dimensiona duas direções: a ordenação cronológica, episódica dos acontecimentos, e a configuração, fundadora do discurso, que remete à forma de expressão.

Outras texturas, segundo Suely Kofes, mostram certa dificuldade em encontrar correspondência entre uma vida como é vivida (o que atualmente acontece); uma vida como experiência (imagens, sentimentos, emoções, pensamentos e significações conhecidas pelas pessoas que as vivenciaram); e uma vida como contada (narrativa, influenciada pelas convenções culturais do contar, pela audiência e pelo contexto). Também existe a dificuldade de se traçar a diferença entre esses distintos planos. Subjetividade evoca que para lembrar é preciso não só vivenciar como tornar conteúdos significativos. Recordar também contempla o experimentar do sujeito, onde novas dobras de subjetividade triscam o estofo do que antes era instituído na tradição contemporânea. Paralelo a certezas esvaídas, “o abismo escancarado, a quebra irremissível no fio do tempo e no contorno da alma” (Pelbart, 2000, p. 7).

\section{Interfaces}

A temática sensível da subjetividade no que se refere à narrativa de seres que pertencem ao mundo e se fazem representar mediante a tradição oral apresenta um desafio da ordem do discurso, uma vez que, "a história oral é uma forma específica de discurso: história evoca uma narrativa do passado; o oral indica um meio de expressão" (Portelli, 2001, p. 10).

A construção de um sentido, como assinalado, na relação entre entrevistado e entrevistador apresenta uma trama que é construída no 
território de sujeitos pressupondo autonomia. A categoria sujeito, como elemento indissociável da autonomia moderna, remonta ao século XVIII. O século XIX aos poucos vai configurando seu estatuto à medida que o projeto iluminista é interpelado em suas bases estruturantes, por pensadores como Nietzsche, Marx e Freud, não lidos, entretanto, em sua época. O sujeito, com seu caráter autônomo, se liga ao conceito de cultura que representa. Segundo Manfredo Araújo de Oliveira, "a autonomia é conceito chave da modernidade, apesar de ser também categoria com uma longa história. Em sua origem grega, ela significou a meta das cidades-estados de poderem determinar suas questões próprias na independência de poderes estranhos. $\mathrm{Na}$ modernidade, na época das guerras de religião, ela exprimia a pretensão de uma autodeterminação religiosa-confessional. Kant a introduziu na esfera da reflexão filosófica e através disto lhe deu a determinidade de exprimir aquilo que o homem tem de mais próprio e que, assim o distingue dos demais seres. A autonomia significa, a partir de então a capacidade e a tarefa que caracteriza o homem como homem, ou seja, de autodeterminar-se e de autoconstruir-se em acordo com as regras de sua própria razão" (Oliveira, 1995, p. 199).

No século XX, a partir de sua segunda metade, a questão da subjetividade emerge aliando-se à de autonomia como forma de apresentar filandras de vozes ocultas que iriam desvelar um outro lado do discurso. Acontecimentos como emergência da subjetividade feminina e grupos socialmente segregados convocam pesquisadores e, de forma particular historiadores, a tentar perceber analiticamente discursos que configuram outro lugar na construção da história.

É neste contexto de desconfiança no que discursa que a história oral se presentifica, dando voz a sujeitos que exercitam sua autonomia, ao escolher dizer o não dito. Pesquisadores e indivíduos comuns marcam suas histórias e de outros, tornando a narrativa uma presença viva de fatos que ocorreram no tempo vivido. Como Aracné, que tece histórias com fios de seu próprio corpo, ao contar histórias o narrador busca um sentido e um significa no tempo. O que é contado torna-se unidade de referência mítica, na qual é possível retornar numa atemporalidade, convocando o pesquisador a escutar a mesma história com significados diferentes. Assim, "a entrevista, implicitamente, realça a autoridade e a autoconsciência do narrador e pode levantar questões 
sobre aspectos da experiência do relator a respeito dos quais ele nunca falou ou pensou seriamente" (Portelli, 2001, p. 12).

Diante de narrativas que registram unidades de referência, o pesquisador interpreta o jogo intrincado da subjetividade que estampa um discurso diferente daquele apresentado pelo documento escrito. Sujeitos narram quem são e como significam seu passado e a história oral registra o evento como acontecimento. Uma nova relação se constitui devido a sujeitos que se fazem escutar, levando pesquisadores a visualizar uma perspectiva ética capaz de emoldurar o campo da narrativa ao enfrentar os desafios da interpretação.

A relação entre sujeitos demanda uma subjetividade que necessita ter por mediação o reconhecimento do outro como pertencente à espécie humana. Sua posição alcançou importância a partir do momento em que instituições de controle, preocupadas com um outro territorializado, perceberam-se em crise. Essas instituições representadas socialmente em lugares definidos como família, religião, escola e estado cuidavam à sua maneira do outro. Outro que tem um nome, um culto, um uniforme, uma língua, um país. Paralelo à crise ocorre uma ausência de sentido nos discursos que tematizam a individualidade. Talvez insuficiência das ciências do psiquismo para escutar novas subjetividades.

É neste exílio do outro territorializado que novas demandas no campo das subjetividades emergentes exigem experiências de sujeitos que signifiquem seu ser no mundo, construindo trajetórias que atribuam sentido ao real. Lugares de memória, modernidades tardias, pósmodernidade, alta modernidade, fulguram em nossos discursos tentando qualificar hiatos criados pela crise de interpretação de narrativas. Estas são construídas e analisadas pelo discurso acadêmico, sem contudo levar em conta sujeitos que constroem significados para sua própria existência.

É a partir desse lugar da significação que o pesquisador da história oral, ao se deparar com sujeitos, deve assumir uma responsabilidade ética, pois a relação sujeito - outro necessita ser contemplada em um processo que envolve individualidades. Cabe ao pesquisador estar circunscrito ao ethos, caracterizado como habitabilidade, termo da arquitetura moderna que significa lugar em que o sujeito se sente bem. $\mathrm{Na}$ perspectiva ética este lugar é com o outro. A relação que se estabelece entre entrevistador e entrevistado é mediada por um respeito às dife- 
renças. Tal respeito convoca-nos a tematizá-lo na fronteira da alteridade. Sendo assim, ao reconhecer o outro enquanto espécie passamos a estabelecer uma relação entre iguais que abre a possibilidade do encontro entre sujeitos.

A autonomia das partes envolvidas no processo de construção de narrativas é de fundamental importância, pois "o sujeito é autônomo quando, vinculando-se a um grupo com suas normas morais, ele as interioriza, e ao refletir sobre as conseqüências de suas decisões, escolhe aceitar a norma ou recusá-las" (Ferreira, 2002, p. 33).

$\mathrm{Na}$ relação entrevistador e narrador, a mediação ética se expressa numa tentativa de construção de projetos autônomos, como assinala Castoriadis quando afirma: "o projeto de construção da autonomia não pode desconhecer as condições e a dimensão sócio-histórica que o influencia (mas não o determina) e, coloca em um suposto sujeito fictício, autárquico em plena conformidade com a lei da razão, a tarefa de desvencilharse das contingências impostas pela realidade" (apud Lopes, 2000, p. 45).

Se entre sujeitos há uma busca de dizer verdades construídas ao longo de uma experiência, essas verdades consolidam-se em narrativas que dão forma ao conteúdo do tempo vivido, tornando verdadeiro o que é proferido. Para Castoriadis, “a verdade própria do sujeito é sempre a participação em uma verdade que o ultrapassa, que enraíza finalmente na sociedade e na história, mesmo quando o sujeito realiza sua autonomia." (apud Lopes, 2000, p. 46).

Ao se pensar a relação entre sujeitos é necessário refletir alguns princípios que se tornem pilares para a ação ética do entrevistador, ao lidar com a verdade do sujeito, uma vez que, "ao narrarem suas histórias, os contadores deixam-se ficar suspensos no tempo, a fim de que o passado esquecido possa ser redescoberto, salvo no presente. A presentificação do passado, ao possibilitar uma experiência da temporalidade do mundo permite, também, que se descubram as sendas do futuro" (Lopes, 2000, p. 46). Os princípios são apenas unidades de referência que abrem possibilidades na opção de ouvir sujeitos não escutados, que demandam cuidado em nossa ação de entrevistadores. Ferreira (2002, p. 38-41) assinala quatro princípios na ação ética do sujeito contemporâneo: o da justiça, o da não-violência, o da solidariedade e o da responsabilidade.

No princípio da justiça, o ideal de ser justo inspira-se no respeito ao outro que se iguala enquanto espécie, mas se diferencia enquanto 
singularidade. É através do senso de justiça existente entre os homens que a lei moral e a ética se objetivam e possibilitam ao sujeito o exercício da autonomia, tendo a liberdade como possibilidade de escolha, ao se tomar decisões. Dessa forma, ser justo é ir livremente em busca da melhor decisão, lembrando que é a ação justa que move os sujeitos no mundo. Não existe modelo de justiça, nem caminhos a serem percorridos para se estabelecer parâmetros de justiça. O princípio da justiça é aliado ao da igualdade de condições mínimas de sobrevivência. Isto implica a exigência permanente de direitos e de oportunidades sociais. Nessa direção, a justiça torna-se um critério para se avaliar um ato, o que nos leva a compreender as desigualdades nas relações entre os sujeitos, levando o ser humano ao exercício da recusa a qualquer tipo de violência.

O princípio da não-violência coloca-nos a possibilidade de respeitar e preservar as diferenças. Este princípio coloca a possibilidade de reconhecimento do outro como um ser que pertence à espécie humana. O outro é compreendido como sendo o próximo, “o próximo pode ser aquele [e é] aquele que me é desconhecido, me enfrenta face a face. É uma relação de parentesco fora de qualquer biologia, contra qualquer lógica. Não é pelo fato de o próximo ser reconhecido como pertencente ao mesmo gênero que ele me concerne. É precisamente por ser o outro. A comunhão com ele começa na minha obrigação para com ele." (Ferreira, apudLopes, 1993, p. 39). Dessa maneira, o outro convoca-me a recusar qualquer forma de violência, pois é o próximo, um ser humano qualquer; pode ser o passante, o turista, o homem da vida urbana, da vida rural, o mestre, o aluno, o estranho. O outro é o primeiro que passa e toca meus sentidos, é o primeiro que chega. Por não ser permitido violar sua integridade física e psíquica, é preciso que se aprenda a não tornar o outro um objeto, uma coisa e não usar a força como mecanismo de coerção. A ética, enquanto forma de interação com o outro, abre campo aos sujeitos para a construção e o exercício da solidariedade ao próximo.

O princípio da solidariedade funda-se em um dever; ela não designa um dever. $\mathrm{O}$ gesto de ser solidário liga-se ao respeito à diferença, em que o ser humano aprende a perceber que o outro também pertence ao mundo. O pressuposto da solidariedade é a interdependência humana. A ação solidária liga-se à construção do sujeito face a ideais demo- 
cráticos e de cidadania; envolve o outro independente de suas escolhas, pois o ser humano é livre na tomada de decisões. O princípio de solidariedade, ao expressar responsabilidade para com o outro, sem esperar reciprocidade, faz lembrar que "o eu tem sempre uma responsabilidade a mais do que todos os outros" (Levinas, 1982, p. 91).

O princípio da responsabilidade possibilita-nos perceber no outro a condição humana, como também abre uma possibilidade de se respeitar as coisas que estão no mundo, pois essas se relacionam com o meu próximo. A responsabilidade pela natureza do mundo está em conceber dentro dele um outro que difere de um eu e necessita aprender que, além da convivência, é preciso preservar o que é de todos. Assim é necessário cultivar o respeito pelo outro em sua singularidade, para que se concretizem os ideais de sobrevivência dos seres e a possibilidade de se viver bem.

Estes princípios assumidos na ação ética do entrevistador abrem possibilidades para se conceber o outro como rosto na expressão de E. Levinas (1982, p. 77), quando afirma que “o acesso ao rosto é, num primeiro momento ético, quando se vê o nariz, os olhos, a testa, um queixo e se podem descrever, é que nos voltamos para outrem como para um objeto. Melhor maneira de encontrar outrem é nem sequer atentar na cor dos olhos. Quando se observa a cor dos olhos não se está em relação social com outrem. A relação com o rosto pode, sem dúvida ser dominada pela percepção mas o que é especificamente rosto é o que não se reduz a ele."

É neste ultrapassar o rosto que o outro se apresenta como pertencente à espécie e mediante a narrativa nos apresenta uma subjetividade de ser no mundo, apresentando textos e vivenciando contextos. O lugar do historiador que trabalha com a oralidade é na escuta sensível de onde emerge a voz de sujeitos que são portadores de uma memória, cuja significação tece fios na história de uma época. Nessa direção, remontamos a Levinas (1982, p. 87), ao pretender que "a ética não aparece como suplemento de uma base existencial prévia, é na ética entendida como responsabilidade que se dá o próprio nó do subjetivo". Portanto, não se trata do narrar por narrar quando alguém deseja dizer sobre si mesmo. Mas, compreende o narrar que abre possibilidades de se apreender uma subjetividade que se mostra na pluralidade de seu tempo. Assim, “a subjetividade não é um para si, ela é mais uma vez 
inicialmente um para o outro. A responsabilidade como responsabilidade por aquilo que não fui eu que fiz, ou não me diz respeito, é por mim abordado como rosto”. (Levinas, 1982, p. 87).

A relação eu e outro na história oral demanda a responsabilidade de se conceber projetos que estejam comprometidos com o outro e com o próprio exercício do fazer histórico. No dizer, o ser que diz ali se coloca num lugar de poder e espera uma contrapartida na contribuição que o mesmo ofereceu. Aqui levantam-se indagações. A que e a quem servem depoimentos orais? Que compromisso ético e moral tem o profissional que desejou utilizar tal metodologia? A que servem depoimentos coletados em suas vertentes de vida e temática? Essas indagações se perdem às vezes no vazio do tempo da escrita. Se os arquivos que colhem documentos escritos têm seu tempo próprio de ser pesquisado por outros, que tempo oferecemos aos arquivos de documentação oral para que sejam pesquisados por outros?

O trabalho de uma memória oral como documento vivo se contrapõe ao olhar muitas vezes descuidado do pesquisador. "O trabalho da memória comporta o tempo de lembrar e do esquecer. É com base nesse inventário de recordações e esquecimentos que sujeitos criam e manipulam representações que serão mobilizadas no cotidiano, nas atividades do pensar e do fazer." (Lopes, 2000, p. 46). O estranhamento do documento oral e sua distância abrem para o pesquisador uma fresta para se compreender o ato de narrar como um desafio de interpretação.

A interpretação está ligada à hermenêutica que, segundo Manuel Antônio de Castro (1994), está etimologicamente de um lado ligada ao verbo hermeneueim, que significa exprimir seu pensamento, fazer conhecer, interpretar, traduzir, comunicar-se, e de outro, a Hermes, mensageiro entre os deuses e os mortais, deus dos caminhos da luz e das trevas, revelador do conhecimento (mas nunca diz toda a verdade), ligado à alquimia e à adivinhação.

É neste dizer uma parte da verdade que a subjetividade de um narrador demanda do pesquisador à procura de significações que lhe permitam compreender, na ordem do discurso, cenas que representem um sujeito e suas autonomias no ato de narrar. Nessa direção, não é o relato pelo relato que contenta o pesquisador, mas as possíveis inferências que o mesmo pode fazer a partir das narrativas. 
Neste impasse se deparam as áreas do conhecimento. A história narra acontecimentos e deles infere hipóteses. Mas, quem narra na história oral é o sujeito autônomo que decidiu narrar. Nesse sentido, há a demanda de uma escuta sensível e de uma demarcação que possibilitem ao pesquisador a análise dos relatos construídos. A interpretação dos documentos é fundamental, mas trata-se de um desafio. Se a hermenêutica está ligada à interpretação do texto numa tentativa de traduzir a relação entre o leitor e o texto, há uma outra relação que, segundo Castro (1994, p. 18) apresenta problemas de ordem diversa: "um texto, desde que produzido, incorpora alguns dados, diante dos quais o leitor tem que tomar posição. Estes dados podem ser internos ou externos e se fazem sentir mais difíceis para compreender, sobretudo, quando há um grande distanciamento histórico. Os externos dizem respeito às referências contextuais inerentes à época de sua elaboração. Já os internos apontam para variações textuais, decorrentes da reprodução pelos copistas e da conservação do texto e para a mudança de significados de certos vocábulos, uma vez que a língua é um todo dinâmico. Ocorre ainda que o autor pode apresentar em sua obra uso característico de vocabulário."

O lado da interpretação que remete a Hermes encerra um conteúdo misterioso. É quando a mediação com o que ultrapassa o texto faz sua morada. Para Castro, a hermenêutica, embora ainda se atenha ao texto, já articula uma realidade transcendente e outra imanente. Partese do domínio gramatical para o correto encaminhamento do sentido figurativo ou alegórico. Ao trazer seu significado etimológico, a hermenêutica apresenta sua dupla face. Historicamente há uma tentativa de se interpretar o texto e se chegar à verdade. De Lutero à atualidade a interpretação apresenta-se como um desafio, buscando compreender o que se diz no que se deseja dizer.

No campo da história oral percebe-se uma ausência de métodos na arte de interpretar seus documentos. Ao pensarmos nas subjetividades e nessa relação com o outro, consideramos pertinente buscar elementos constitutivos à fundamentação no campo da interpretação. Paul Ricoeur tem se apresentado, na tradição contemporânea, como um expoente nessa preocupação de se compreender o dito distanciando-se em parte da pretensão psicanalítica e concentrando-se na linguagem. Torna-se "necessária a mediação entre os seres humanos e, também é 
necessária a mediação da cultura e, portanto, do conhecimento" (Gross, 1999, p. 35).

A linguagem, ao estabelecer a mediação entre ouvinte e narrador, demarca para pesquisadores a necessidade de se compreender o ocorrido no tempo das narrativas. Sendo assim, o mundo do texto é considerado por Ricoeur como referente: "o mundo do texto é uma proposição de mundo. É um mundo ideal. É justamente em diálogo com o seu contexto específico que um texto produz o seu próprio mundo. Por mais irreal que seja, trata-se sempre de uma construção a partir do contexto da produção textual." (Idem, p. 40).

Nessa direção, o narrador expressa em sua fala seu contexto ideal, pois traz de volta coisas perdidas no tempo. Ele as significa e as coloca em movimento como um mecanismo de compor pedaços de uma história que, ao ser vivida, demonstra a possibilidade de trazer dados que se conectam com o imaginário da época. Ao que tudo indica, o narrador diz de um mundo que ele construiu com cacos que restaram do passado. Este mundo representa para o ouvinte histórias que têm seu valor, de forma individual ou coletiva. Isto porque "o mundo contado, é o mundo do personagem e é contado pelo narrador" (Ricoeur, 1995, p. 147).

O narrador oferece ao ouvinte eventos que correspondem ao mundo do texto em sua singularidade, abrindo frestas para se perceber que o discurso unívoco é impossível, uma vez que há uma pluralidade de possibilidades no ato de se interpretar. Então, ficamos com esse desafio: "interpretar é confrontar a proposição de mundo do texto com as possibilidades existenciais do intérprete no seu próprio mundo, é lógico que a interpretação é sempre um processo relativo, sujeito às vicissitudes do tempo" (Gross, 1999, p. 40).

Concebemos fios trançados numa dupla interconexão: "memória e subjetividade. Instituem um lugar de reflexão. A primeira nos conduz ao elo identitário que une o presente ao passado. Seduzidos ficamos pelas nascentes, aquela escura e misteriosa região 'Madres' - de onde ascende a superfície da terra tudo que tem figura e vida". (Holanda, 1991, p. 453). Trata-se de uma matriz de excelência na interpretação do presente. Lembranças valem pelo que dizem e pelo que criam. Produzem vínculos identitários e perfilam o fazer-se sujeito, através das próprias palavras que vão inaugurando os relatos. 
A segunda, a subjetividade, remete-nos a possíveis fundamentos no fazer-se da narrativa: a ética e a interpretação. Perspectivas e desafios nos saberes da história oral. Forjam um amálgama de senhas de intervenção no contexto das histórias narradas. Presentificam o passado sobre o fundo intrincado da lembrança e do discurso, instâncias simbólicas da relação com o outro. Representam e configuram o conhecimento para se apreender o itinerário das jornadas de sujeitos.

A subjetividade apresenta um domínio próprio, uma visibilidade que permite percebê-la não como algo dado. Peter Felbart (2000, p. 12) assinala que pode-se concebê-la como "produzida, moldada, modulada" e talvez automodulável. A construção social e histórica da subjetividade segundo o autor, passa pela reflexão de pensadores, entre os quais Nietzsche e Foucault, que mostram seus deslocamentos da violência à crueldade para inscrever o sujeito em um "mínimo de civilização, de memória, de culpa, de senso de promessa e dívida, em suma, de moral" (Idem, p. 19) Chegou-se a métodos incluso o apedrejamento, o dilaceramento, o pisoteamento por cavalos, o empalamento etc. Hoje há variantes tecnológicas mais sutis para moldar o corpo, marcá-lo, demarcá-lo. Do que se pode depreender que a subjetividade, moldagem humana histórica, torna-se complexa e mutante, o que abre perspectivas e cria desafios à sua interpretação.

Não ficamos presos a uma configuração reassegurada da subjetividade. Embora mutilada, esgarçada, devassada pela representação exarcerbada do individualismo contemporâneo e seus avatares, podese pensar em novos agenciamentos, novos sentidos, novos poderes capazes de afetá-la. Que novas forças seriam estas? Sabemos que nossos territórios trançam fronteiras de mobilidade que deslocam lugares familiares de abrigo para o nosso corpo, passando pelos nossos cultos até nossos afetos. Entretanto, o sujeito não deixa de subsistir apesar de dividido, despedaçado, deslocado pela velocidade de temporalidades fugazes.

Um personagem de Eduardo Pavlovsky anuncia a gesta destes novos modos de vida: "basta de vínculos, nunca mais vínculos, apenas contigüidades" (apud Pelbart, 2000, p. 19). Entretanto, seria possível desafiar a tirania das "relações de trocas produtivas" e da "circulação social"? Subjetividades parciais podem ser vividas e revividas numa comunidade de significações mediada pela ética. Esta perspectiva nos insere em novas dobras da narrativa e na complexidade de sua interpretação. 
Talvez seja conveniente retomar Ricoeur quando cobre o suposto entre o que é vivido e a vida como experiência, e a construção identitária do eu modulado e intercambiável em seu encontro com o outro. Também remontar a Levinas quando indaga sobre o ser humano, e sua resposta assume a forma narrativa. Para o autor é preciso que alguma coisa aconteça ao eu, para que este deixe de representar uma força em movimento, acordando para princípios de convivência, acordando para o outro que, no caso, significa a revelação do rosto. Há encontro, revelação e não conhecimento. A possibilidade da leitura do rosto significa que o outro não é um objeto ao alcance do eu, mas o seu próximo. Lavramos assim a existência de outros territórios e novos poderes, moldando sujeitos e narrativas.

Resumo: Este artigo examina possíveis categorias que configuram a narrativa, ou seja, memória e subjetividade no percurso do outro. Tece questões que abrem novas perspectivas para se interpretar narrativas no plano da história e do discurso, registrando seus desafios. Analisa a oralidade e seus desdobramentos na travessia do relato individual e singularizado, para a engenhosa construção do coletivo.

Palavras-chave: narrativa; subjetividade; interpretação; ética.

Narrative in the Trama of Subjectivity: Perspectives and Challenges

Aвstract: This article examines possible categories that shape narrative, that is, memory and subjectivity in the trajectory of the other. It weaves questions that open new perspectives to interpret narratives on the plane of history and discourse, taking note of their challenges. It analyzes orality and its evolutions in the passage of the individual, particularized account to the artful construction of the collective.

KEYWORDS: narrative; subjectivity; interpretation; ethics.

\section{Referências bibliográficas}

CALDAS, Alberto. A noção de cápsula narrativa: a entrevista, o texto e o outro na hermenêutica do presente. Disponível em: www.unir.br. Acessado em 27.07.01.

CASTRO, Manuel Antônio. Tempo de metamorfose. Rio de Janeiro: Tempo Brasileiro, 1994.

FERREIRA, Amauri Carlos. Ensino religioso nas fronteiras da ética. $2^{a}$ ed. 
Petrópolis: Vozes, 2002.

GIRON, Loraine Slomp. Da Memória nasce a História, In: LENSKIJ, Tatiana e HELFER, Nadir Emma (org.). Santa Cruz do Sul: EDUNISC / ANPUH, 2000.

GROSS, Eduardo. Hermenêutica e Religião a partir de Paul Ricoeur. Revista de Estudos e Pesquisa em Religião, NUMEN, Juiz de Fora, p. 33-49, 1999.

GROSSI, Yonne de Souza. O enigma da identidade. Cadernos de Ciências Sociais, PUC-MG, Belo Horizonte, v. 5, n. 8, dez. 1999.

KOFES, Suely. Uma trajetória em narrativas. Campinas: Mercado de Letras, 2001.

LEVINAS, E. Ética e infinito. Lisboa: Ed. 70, 1982.

LOPES, Etelvina Pires Nunes. O outro e o rosto: problemas na alteridade em E. Levinas. Braga: Portugal, 1993.

LOPES, José Carlos Cacau. A voz do dono e o dono da voz. São Paulo: Hucitec, 2000.

MITRE, Antônio. Memória y olvido en la historiografia. Belo Horizonte: UFMG, 2001, mimeo.

NUNES, Benedito. O tempo na narrativa. São Paulo: Ática, 1988.

OLIVEIRA, Manfredo de Araújo. Ética e práxis histórica. São Paulo: Ática, 1995.

PASSERINI, Luisa. Mitobiografia em História Oral. Revista Projeto História, PUCSP, São Paulo, 1993.

PAULA, João Antônio. Uma herança humanista. Belo Horizonte: UFMG, 2001, no prelo.

PELBART, Peter Pál. A vertigem por um fio. São Paulo: lluminuras, 2000.

PERELMUTTER, Daisy. A história oral e a trama sensível da subjetividade. Internacional Oral History Conference Proceedings. Rio de Janeiro, 1998.

PORTELLI, Alessandro. A filosofia e os fatos. Revista Projeto História. PUC-SP, São Paulo, 1996, mimeo.

. História Oral como Gênero. Revista Projeto História, PUC- SP, São Paulo, n. 22, jun/2001.

RICOEUR, Paul. Le temps et les philosophies. Paris: Payot / UNESP, 1978. t. II. . Tempo e narrativa. Trad. Marina Appenzeller. São Paulo: Papirus, 1995, Temps et récit. Paris: Seuil, 1983, t. I.

THOMPSON, Paul. A voz do passado: história oral. Rio de Janeiro: Paz e Terra, 1992. 